14. Борисова Е.А., Шилов М.П., Курганов А.А. Флора и растительность озера Поныхарь // Научные труды Национального парка «Хвалынский»: материалы II всероссийской научно-практической конференции. Вып. 7. Саратов-Хвалынск: Амирит, 2015. C. $76-80$.

15. Серегин А.П. Флора Владимирской области: Конспект и атлас. Тула: Гриф и К, 2012. 620 с.

16. Сорокин А.И. Дополнения к флоре мхов Ивановской области // Бюллетень МОИП. Отдел биологический. 2015. Т. 120, вып. 3. С. 72-74.

17. Герасимов Ю.Н., Сальников Г.М., Буслаев С.В. Птицы Ивановской области. М.: Типография Россельхозакадемии, 2000. 125 c.
18. Борисова Е.А., Курганов А.А. Новые и редкие виды растений Ивановской области // Ботанический журнал. 2015. Т. 100, № 5. С. 504-507.

19. Галкина М.А., Виноградова Ю.К. К вопросу о гибридогенном происхождении Bidens $\times$ decipiens Warnst // Российский журнал биологических инвазий. 2019. № 3. С. 13-23.

20. Борисова Е.А., Курганов А.А. Сведения о нахождении новых и редких видов в Ивановской области // Бюллетень МОИП. Отдел биологический. 2019. T. 124 , № 3. C. $32-36$.

21. Серегин А.П. Экспансии видов во флору Владимирской области в последнее десятилетие // Ботанический журнал. 2010. Т. 95, № 9. С. 1254-1268.

\title{
BIODIVERSITY OF LAKE CHERNOE (TAKOVETS), A SPECIALLY PROTECTED NATURAL AREA IN THE IVANOVO REGION
}

Borisova Elena Anatolyevna, doctor of biological sciences, professor, head of General Biology and Physiology Department

Kurganov Anton Aleksandrovich, candidate of biological sciences, associate professor of General Biology and Physiology Department

Lazareva Olga Germanovna, head of Training Laboratory of General Biology and Physiology Department Ivanovo State University (Ivanovo, Russian Federation)

Markov Dmitriy Sergeevich, candidate of geographical sciences, associate professor of History, Geography and Ecology Department Shuya Branch of Ivanovo State University (Shuya, Ivanovo Region, Russian Federation)

Abstract. The paper deals with some questions of specially protected natural areas (SPNA) of the local level Lake Chernoe (Takovets) is located in Lezhnevo municipal District of the Ivanovo Region and it was founded as a SPNA in 1975, in 2001 it became a SPNA of the local level. The area of the lake is 10,8 hectares, the area of the SPNA is 17 hectares. The paper contains data of a complex ecological study: the lake's parameters, the topography of the banks and soil, the features of its flora, vegetation and fauna. 256 vascular plant species from 5 departments, 6 classes, 62 families and 164 genera were registered by 2019. 13 plant species are rare for the Ivanovo Region flora, among them 3 species (Nuphar pumila, Rubus chamaemorus, Rubus nessensis) are included into the Red Data Book; their populations are briefly characterized. The species composition of mosses is diverse (29 species were noted in total). The fauna is typical of small closed region lakes. The lake is pressed by anthropological factors, its ecosystems are disturbed, it promotes invasive alien plants (there are 28 alien plant species). The lake has a great hydrological, scientific and environment-forming value, it is perspective for ecological tourism planning.

Keywords: specially protected natural areas (SPNA); lakes; bathymetric schema; plant communities; flora; populations of rare plant species; alien and invasive plant species; mosses species; features of fauna; Red Data Book; Lezhnevo District; Ivanovo Region.

$$
* * *
$$

\section{ВЛИЯНИЕ АРИДИЗАЦИИ НА ОСОБЕННОСТИ СУБСТРАТНОГО И БИОТОПИЧЕСКОГО РАСПРЕДЕЛЕНИЯ ВИДОВ ГРИБОВ РОДА РОLYPORUS S.L. ЮГО-ВОСТОКА ЗАПАДНОЙ СИБИРИ}

Власенко Вячеслав Александрович, кандидат биологических наук, старший научный сотрудник лаборатории низших растений

Власенко Анастасия Владимировна, кандидат биологических наук, старший научный сотрудник лаборатории низших растений

Центральный сибирский ботанический сад СО РАН (2. Новосибирск, Российская Федерация)

Турмунх Дэжидмаa, $\mathrm{PhD}$, старший научный сотрудник лаборатории патологии растений Научно-исследовательский институт защиты растений Монголии (г. Улан-Батор, Монголия)

Аннотащия. Изучены особенности субстратного и биотопического распределения видов грибов рода Polyporus s.1. юго-востока Западной Сибири. Большинство видов имеют широкий спектр субстратов, представленных различными видами древесных растений. Наиболее широко распространенные и часто встречающиеся виды способны осваивать большой спектр субстратов. Редкие виды отличаются узким субстратным 
спектром. Для редкого вида P. rhizophilus, адаптированного к существованию в условиях субаридных регионов, встречающегося лишь в сообществах степного биома, единственным субстратом являются степные злаки (Stipa, Festuca). Большинство видов растет на древесине лиственных деревьев, лишь некоторые виды могут расти на хвойных деревьях, и только таежный вид $P$. tubaeformis развивается исключительно на хвойных в горных районах. Субстраты грибов представлены 11 видами покрытосеменных, 3 видами голосеменных древесных растений и степными травами. Большинство видов распространены в многочисленных сообществах, все они отличаются высокой частотой встречаемости и заселяют широкий спектр субстратов. Биотопически узко специализированные виды немногочисленны, они характеризуются узкой субстратной специализацией. В антропогенных местообитаниях отмечено 6 видов из 14, растущих в естественных природных сообществах. На равнинной территории выявлено 10 видов рода Polyporus, в то время как 14 видов были обнаружены в горных системах, так как горные гумидные районы содержат наибольший спектр субстратов для грибов. Наибольшее разнообразие видов Polyporus отмечено в темнохвойных лесах, среди которых по числу видов лидируют черневые осиново-пихтовые леса. С увеличением аридизации и сменой растительных сообществ элиминируются редкие реликтовые горно-таежные, неморальные, а также типичные таежные виды. Наименьшее число видов Polyporus встречается в степных сообществах субаридных регионов.

Ключевые слова: грибы; Polyporus; субаридные регионы; гумидные регионы; полипороидные грибы; экологическая структура; экологическое разнообразие; распределение; субстратная специфичность; местообитания; Западная Сибирь; равнина; горы.

\section{Актуальность}

Аридизация среды обитания принимает глобальный характер и влияет на видовое и экологическое разнообразие различных групп организмов. В настоящем исследовании изучено влияния аридизации климата на распределение афиллофороидных грибов в растительных сообществах юга Западной Сибири на примере модельного рода Polyporus s.l.

Для выявления влияния аридизации климата на таксономическую структуру модельного рода в границах района исследования было проведено сравнительное изучение географического распространения, субстратной приуроченности, распределение по типам растительных сообществ - показателей, непосредственно зависящих от климатического режима природной территории.

В ходе проведенных исследований ряд видов впервые был выявлен нами для регионов юго-востока Западной Сибири: P. alveolaris, $P$. arcularius, $P$. tuberaster, P. umbellatus - для Алтайского края, P. ciliatus, P. tubaeformis - для Новосибирской области. Определена частота встречаемости видов, показано распределение видов по субстратам, типам растительных сообществ, широтным зонам и высотным поясам.

\section{объект исследования}

Род Polyporus - один из наиболее крупных морфологических родов деревообитающих полипороидных грибов (сем. Polyporaceae), состоящий из нескольких филогенетических обособленных линий, выделяемых некоторыми авторами в рамках самостоятельных таксонов родового уровня. Polyporus s.l. затрагивает комплекс филогенетических таксонов, со сходной морфологией и типом жизненной формы, относящихся в свете современных таксономических трендов помимо собственно Polyporus - к родам Cerioporus, Favolus, Lentinus, Neofavolus, Picipes.

Характерные признаки Polyporus s.l. - плодовые тела со шляпкой и ножкой, выраженной или зачаточной, одинарной или разветвленной, димитической гифальной системой с арбориформными скелето-связывающими гифами, цилиндрическими, гладкими базидиоспорами, цистиды гимении отсутствуют, вызывают белую гниль древесины.

В классической монографии Nunez \& Ryvarden [1] в роде Polyporus s.l. было описано 32 вида. С уче- том возрожденных видов, а также найденных и описанных в последнее время как новые для науки, род может насчитывать порядка 55 видов, более половины из которых встречаются на территории Северной Евразии, 14 видов отмечены в Западной Сибири.

Представители морфокомплекса Polyporus s.1. являются ценными объектами биотехнологии. Их биологически активные метаболиты обладают лекарственными свойствами [2]. В природе виды рода Polyporus широко распространены и выполняют функцию в лесных экосистемах по утилизации мертвой древесины, вызывают белую гниль [3; 4].

Несмотря на достижения в изучении филогении рода Polyporus s.1. [5-9], в нашем исследовании данный искусственный морфологический таксон рассматривается в широком смысле, так как остается много вопросов, связанных с филогенией его отдельных эволюционных линий и их отношений. Он включает в себя виды, отличающиеся по отношению к параметрам среды - температуре и увлажнению, в связи с чем его удобно использовать в сравнительных целях при проведении анализа дифференциации видов грибов в градиенте аридизации.

\section{Материалы и методика исследований}

Цель работь: изучение особенностей субстратного и биотопического распределения видов грибов рода Polyporus s.l. юго-востока Западной Сибири.

Район исследования находится в северной Азии и представляет собой юго-восточную часть Западной Сибири, включая равнинную территорию ЗападноСибирской низменности и часть Алтае-Саянской горной области (рис. 1). Грибы выявлены в 67 локалитетах, в 21 типе растительных сообществ, 14 типах растительных формаций. Подробная характеристика локалитетов дана в нашей предыдущей работе [10].

В результате собрано и проанализировано 260 гербарных образцов, включающих 14 видов грибов рода Polyporus s.1.

Плодовые тела грибов собирали в процессе экспедиционных исследований, проводившихся на юговостоке Западной Сибири в течение 2007-2015 гг. [11-15]. Кроме естественных лесных сообществ были также обследованы антропогенные местообитания, с представленными в них искусственными насаждениями и остатками естественных растительных сообществ в пределах г. Новосибирска. 


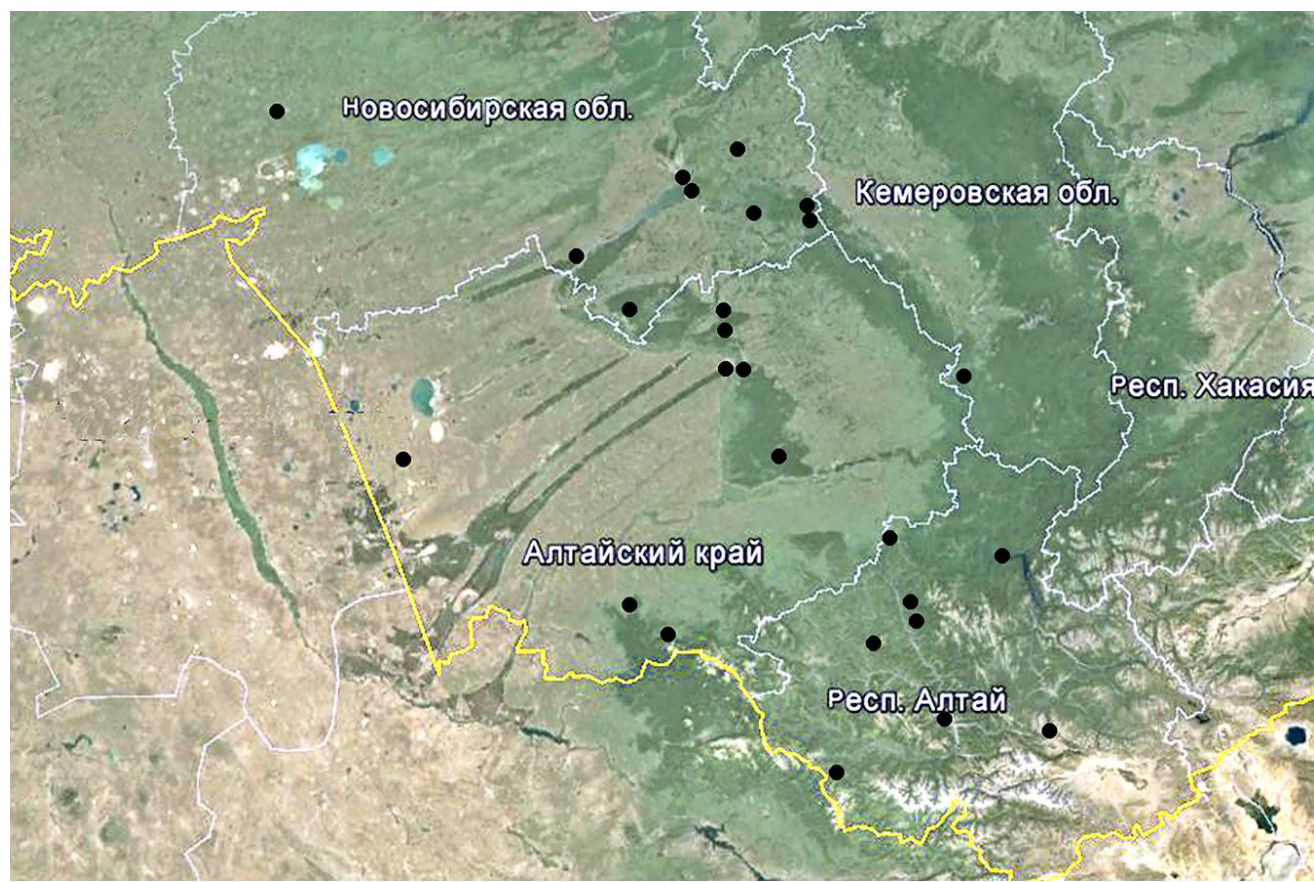

Рисунок 1 - Район исследования и локалитеты сбора материала

Высушенные образцы были сохранены в гербарии. Информация по субстратной приуроченности и местообитаниям грибов была занесена в базу данных Excel и использована в настоящем исследовании. Распределение видов рода Polyporus по регионам на изученной территории, а также по равнинным субаридным и гумидным горным территориям приведено в табл. 1.

Таблица 1 - Распределение видов рода Polyporus на юго-востоке Западной Сибири

\begin{tabular}{|l|c|c|c|c|c|c|}
\hline \multicolumn{1}{|c|}{ Виды } & АК & НО & РА & КО & С & $\Gamma$ \\
\hline P. alveolaris & + & $!$ & + & + & - & + \\
\hline P. arcularius & + & + & + & + & + & + \\
\hline P. badius & + & + & + & + & + & + \\
\hline P. brumalis & + & + & + & + & + & + \\
\hline P. choseniae & - & - & + & - & - & + \\
\hline P. ciliatus & + & + & + & $!$ & + & + \\
\hline P. melanopus & + & + & + & $!$ & + & + \\
\hline P. pseudobetulinus & + & + & + & + & + & + \\
\hline P. rhizophilus & + & + & + & + & + & + \\
\hline P. squamosus & $!$ & + & + & $!$ & + & + \\
\hline$P$. tubaeformis & $!$ & + & $!$ & $!$ & $!$ & + \\
\hline$P$. tuberaster & + & + & + & + & + & + \\
\hline$P$. umbellatus & + & $!$ & + & $!$ & - & + \\
\hline$P$. varius & + & + & + & + & + & + \\
\hline
\end{tabular}

Примечание. «+» - вид известен; «-» вид не отмечен; «!» - ожидаемый вид; $A K$ - Алтайский край; $H O$ - Новосибирская область; $P A$ - Республика Алтай; $K O$ - Кемеровская область; $C$ - равнинные субаридные территории; $\Gamma$ - горные гумидные территории.

\section{Результаты исследования и их обсуждения}

Субстратная дифференциация видов рода Polyporus специфична. Большинство видов имеют широкий спектр субстратов, насчитывающий 6 ( $P$. varius), 5 (P. arcularius, P. brumalis, P. ciliatus, P. tuberaster) или 4 (P. badius, P. melanopus) видов древесных растений. Также следует отметить, что все эти виды яв- ляются часто встречающимися. Немногие виды развиваются на 2 (P. squamosus) или 3 (P.alveolaris) субстратах. Все остальные виды имеют узкий спектр субстратов и приурочены к осине (P.pseudobetulinus), ивам (P. choseniae и P. umbellatus), пихте сибирской (P.tubaeformis) и степным злакам (Stipa, Festuca) P. rhizophilus, которые для данного вида в условиях степного биома являются здесь единственным субстратом.

Большинство видов растет на древесине лиственных деревьев (12 видов), из этих 3 вида (P. ciliatus, $P$. melanopus, $P$. varius) могут расти на хвойных деревьях. На хвойных в целом может расти 4 вида, из которых только P.tubaeformis развивается исключительно на них. 1 вид (P. rhizophilus) не связан с лесом и представляет собой типичный ксеротолерантный вид, характерный исключительно для субаридных регионов.

Субстраты грибов представлены 11 видами покрытосеменных, 3 видами голосеменных древесных растений и степными злаками (Stipa, Festuca). Виды распределены по субстратам следующим образом: на ивах (10 видов), осине (8), березе (6), черемухе (4), липе (3), пихте сибирской (2). На других субстратах растут по 1 виду: на сосне сибирской, карагане древовидной, ольхе, боярышнике, орехе маньчжурском, яблонях, бузине, рододендроне, лиственнице сибирской, пихте сибирской, на травах.

Все находки на рябине, карагане, рододендроне сделаны в горах и относятся к P.alveolaris. Вид $P$. arcularius растет на бузине в кустарниковых сообществах горных осыпей - курумах. Только $P$. tuberaster был найден на ольхе и орехе маньчжурском, $P$. squamosus - на яблонях в искусственных насаждениях городов.

Виды рода Polyporus на хвойных деревьях растут только в горных районах. На лиственнице сибирской развивается только P.varius. На пихте сибирской растут только P. tubaeformis и P. melanopus, на пихте сибирской - только P. ciliatus.

Таким образом, наибольший спектр субстратов для видов грибов рода Polyporus на юго-востоке Западной Сибири характерен для гумидных районов. 
Некоторые древесные породы (орех маньчжурский и яблони) были отмечены в качестве субстратов грибов лишь на антропогенных территориях, где на них способны развиваться виды, отличающиеся широкой экологической амплитудой. В субаридных районах в качестве субстрата грибов встречаются лишь береза, осина, черемуха, а также различные виды ив. Необходимо заметить, что данные древесные породы являются основным субстратом также и в гумидных районах.

Биотопическая дифференциация видов рода Polyporus, как и субстратная, заметно варьирует. Мы дифференцировали исследованные биотопы по выделенным растительным формациям, которых насчитывается 14. Один тип формаций может встречаться в различных широтных зонах и высотных поясах, поэтому внутри них выделены отдельные группы. Таким образом, принимая во внимание зональное распределение, был определен 21 тип растительных сообществ.

Большинство видов распространены в многочисленных сообществах: P. arcularius, P. badius, P. brumalis, $P$. ciliatus, $P$. melanopus, $P$. tuberaster, $P$. varius. Все эти виды отличаются высокой частотой встречаемости и заселяют широкий спектр субстратов. Среди них виды, специфичные для субаридных природных территорий, отсутствуют.

Узко специализированные по биотопическому признаку виды отмечены как среди типичных мезофитов, так и среди ксерофитов. Узкую биотопическую специализацию имеют виды P. pseudobetulinus, P. rhizophilus. Только к одному типу сообществ были приурочены 4 вида: P. alveolaris и P.tubaeformis населяющие черневые леса; P. choseniae - прирусловые горные субальпийские лиственничные леса; P. umbellatus - ивово-березовые прирусловые леса горных регионов.

Проведено разделение видов по группам частоты встречаемости: к редким видам относятся: P. umbellatus $(0,4 \%$ от всех записей), P. tubaeformis $(0,4 \%)$. Изредка встречающиеся виды: P. choseniae $(0,8 \%)$, P.rhizophilus (1,2\%). Обычные виды: P. squamosus
(1,5\%), P. alveolaris (1,9\%), P. pseudobetulinus $(2,7 \%)$. Часто встречающиеся виды: P. tuberaster (4,6\%), P. melanopus $(5,8 \%), P$. arcularius $(10,0 \%), P$. ciliatus $(11,2 \%)$, P. badius (13,8\%), P. brumalis (16,9\%), P. varius $(28,8 \%)$.

Распределение видов рода Polyporus значительно отличается в зависимости от типа растительных сообществ (рис. 2). Наибольшее разнообразие видов наблюдается в черневых осиново-пихтовых лесах (10 видов).

Среди растительных формаций были определены семь типов. Виды рода Polyporus распределены по ним следующим образом (в порядке убывания): темнохвойные леса (11 видов), светлохвойные леса (9), лиственные леса (9), антропогенная растительность в городах (6), кустарниковая растительность (1), «настоящие» степи (1), луговые степи (1).

Анализ распределения по типам растительности показывает, что все 14 видов рода Polyporus можно найти в естественных растительных сообществах, в том числе 13 видов в лесах, 1 вид в кустарниковом типе растительности, но 4 вида встречаются в кустарниковых сообществах лесов, 1 вид в степи. Шесть видов найдено в антропогенной растительности.

\section{Выводы}

Распределение видов рода Polyporus на юговостоке Западной Сибири связано с экологическими предпочтениями видов. Распределение видов по отдельным регионам в целом согласуется с распределением видов по равнинным и горным территориям и зависит от характера их природной среды.

Виды P. arcularius, P. badius, P. brumalis, P. tuberaster, P. varius, отличающиеся частой встречаемостью и широким субстратным спектрам, обнаружены во всех регионах. Часто встречающиеся виды P. mеlanopus, P. ciliatus выявлены не во всех регионах, но это связано лишь с их недостаточной изученностью, эти виды, с большой долей вероятности, будут выявлены в них в будущем. Некоторые обычно встречающиеся виды, например P. badius и узкоспециализированный $P$. pseudobetulinus, также представлены во всех регионах.

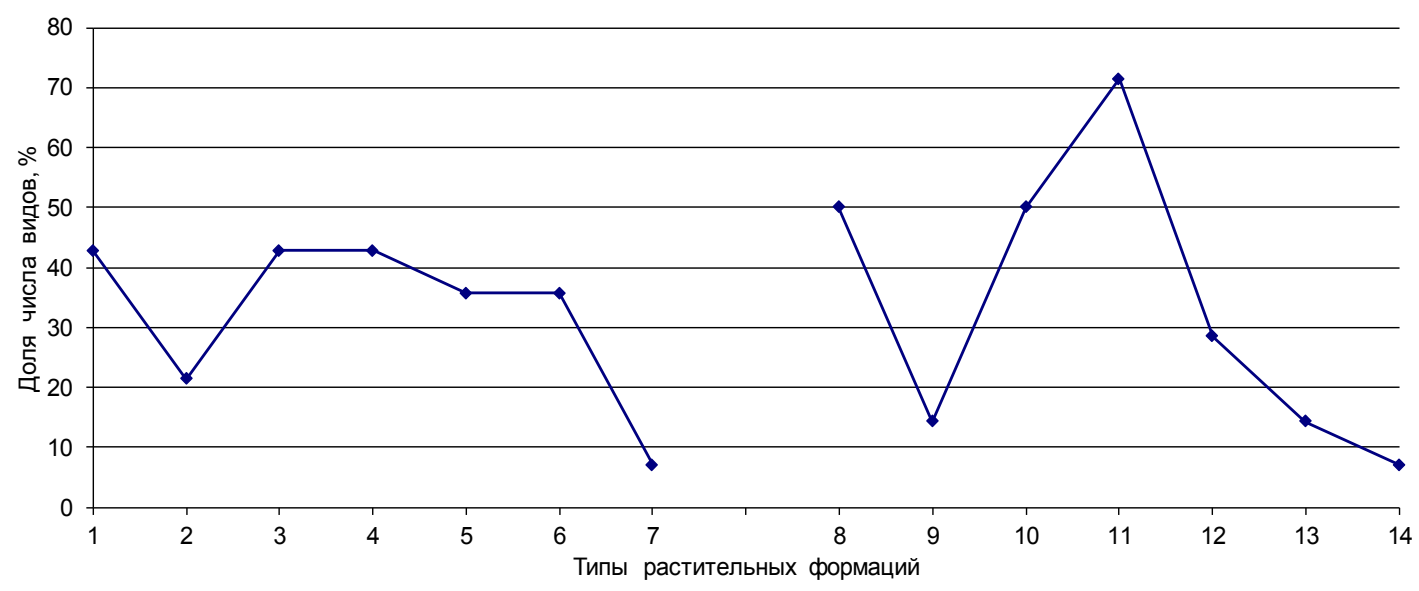

Рисунок 2 - Распределение числа видов рода Polyporus (в \%) района исследований

по типам растительных формаций субаридных равнинных, субаридных и гумидных горных территорий.

1-7- равнинная территория: 1- посадки в городах, 2- прирусловые сообщества малых рек, 3- подтаежные сосновые и мелколиственные травяные леса,

4- лесостепные сосновые леса правобережья Верхнего Приобья - «Приобские боры»,

5- лесостепные сосновые леса левобережья Верхнего Приобья - «Ленточные боры», 6- лесостепные колочные мелколиственные леса, 7- степные сообщества;

8-14- горные территории: 8- прирусловые мелколиственные леса, 9- кустарники скалистых осыпей, 10 - подтаежные мезофитные сосновые леса, 11 - реликтовая низкогорная «черневая тайга», 12 - темнохвойные леса, 13 - горная лесостепь, 14- горная степь 
Вид P.alveolaris, вероятно третичный реликт хвойно-широколиственных лесов, обнаружен нами лишь в горных регионах. Он пока не был выявлен в Новосибирской области, но может быть встречен на Салаирском кряже.

Вид $P$. choseniae, который также считается реликтовым, обнаружен нами лишь в горных регионах, на Алтае, на валежных ивах в прирусловых лиственничниках, заходящих по рекам в межгорные котловины. На равнине данный вид не встречается, имеющиеся в литературе указания на нахождение здесь этого вида основаны на неверных определениях.

Редкий вид P. umbellatus, как и вышеуказанные реликтовые виды, обнаружен лишь в горных регионах в прирусловых лесах.

В отличие от редких видов, вероятно имеющих реликтовый характер на территории юго-востока Западной Сибири, вид $P$. tubaeformis является типично таежным, поэтому он был обнаружен или может быть обнаружен в будущем в таежных и горнотаежных регионах.

Редкий вид P. rhizophilus выявлен как на равнине, так и в горах, в пределах степного биома.

В целом 10 видов рода Polyporus были обнаружены на равнинной местности, 14 видов были обнаружены в горных системах, так же как и в районе исследований в целом. Анализ зонального распределения видов показывает, что наиболее разнообразие видов рода Polyporus наблюдается в гумидной горнотаежной зоне. P.alveolaris и P. choseniae на юговостоке Западной Сибири специфичны для гор.

Анализ географического распространения, таксономической и экологической структуры рода Polyporus позволяет сделать вывод, что с увеличением аридизации и сменой растительных сообществ элиминируются редкие реликтовые (горно-таежные и неморальные) и таежные виды. На субаридных территориях в естественных природных местообитаниях никогда не встречаются P.alveolaris, P.choseniae, P. tubaeformis, P. umbellatus.

Виды, встреченные как в субаридных, так и гумидных районах: P. arcularius, $P$. brumalis, $P$. ciliatus, P. melanopus, P. tuberaster, P. varius. Проведенное для данных видов сравнение относительной встречаемости показало, что среди них наиболее часто в субаридных регионах встречаются виды (в порядке убывания): P.arcularius, P. ciliatus, P. tuberaster, P. brumalis, $P$. varius, $P$. melanopus.

Исключительно в субаридных равнинных районах и аридных горах встречается P. rhizophilus, развивающийся в степях как паразит на корнях злаков. В связи с сильным сокращением площадей степей и большой антропогенной нагрузкой на данные сообщества, данный вид рекомендуется включать в Красные книги всех регионов, где он отмечен.

\section{Список литературы:}

1. Nunez M., Ryvarden L. Polyporus (Basidiomycotina) and Related Genera. Oslo: Fungiflora, 1995. $85 \mathrm{p}$.

2. Власенко В.А., Власенко А.В., Анькова Т.В., Косогова Т.А., Теплякова Т.В. Лекарственные грибы рода Полипорус (Polyporus P. Micheli ex Adans, Polуроraceae) Новосибирской области // Иммунопатология, аллергология, инфектология: Труды междисци- плинарного микологического форума. Т. 2, № 2. М.: Общероссийская общественная организация Общественная национальная академия микологии, 2009. C. $168-169$.

3. Ryvarden L., Gilbertson R.L. European polypores. Part 2: Meripilus-Tyromyces. Synopsis Fungorum 7. 1994. P. 388-743.

4. Ryvarden L., Melo I. Poroid fungi of Europe. Oslo: Fungiflora, 2014. 456 p.

5. Krüger D., Gargas A. The basidiomycete genus Polyporus - an emendation based on phylogeni and putative secondary structure of ribosomal RNA molecules // Feddes Repertorium. 2004. Vol. 115, № 7-8. P. 530546.

6. Krüger D., Petersen H.R., Hughes W.K. Molecular phylogenies and mating study data in Polyporus with special emphasis on group «Mealnopus» (Basidiomycota) // Mycological Progress. 2006. Vol. 5. P. 185-206.

7. Sotome K., Hattori T., Ota Y., To-anun Ch., Salleh B., Kakishima M. Sotome. Phylogenetic relationships of Polyporus and morphologically allied genera // Mycologia. 2008. Vol. 100, № 4. P. 603-615.

8. Zhou J.-L., Zhu L., Chen H., Cui B.-K. Taxonomy and Phylogeny of Polyporus Group Melanopus (Polyporales, Basidiomycota) from China // PLoS ONE. 2016, Vol. 11, № 8: e0159495.

9. Zmitrovich I.V., Kovalenko A.E. Lentinoid and Polyporoid Fungi, Two Generic Conglomerates Containing Important Medicinal Mushrooms in Molecular Perspective // International Journal of Medicinal Mushrooms, 2016. Vol. 18 (1). P. 23-38.

10. Vlasenko V.A., Vlasenko A.V. Diversity, distribution and ecology of the genus Polyporus south of Western Siberia (north Asia) // Current Research in Environmental \& Applied Mycology. 2015. Vol. 5, № 2. P. 82-91.

11. Власенко В.А. Трутовые грибы (Polyporaceae s.1.) сосновых лесов лесостепной зоны правобережья Оби // Микология и фитопатология. 2010. Т. 44, вып. 1. С. 3-9.

12. Власенко В.А. Новинки рода Polyporus (Polyporaceae, Basidiomycota) для микобиоты Алтая // Растительный мир Азиатской России. 2010. Т. 5, № 1. C. $29-32$.

13. Власенко В.А. Род Polyporus (Polyporaceae, Ваsidiomycota) в лесостепной зоне Западной Сибири // Растительный мир Азиатской России. 2011. Т. 8, № 2. C. 9-14.

14. Власенко В.А., Власенко А.В. Афиллофороидные грибы памятника природы «Бердские скалы» (Новосибирская область) в предгорных районах Салаирского кряжа // Научные ведомости БелГУ. Серия Естественные науки. 2017. № 25 (274). Вып. 41. C. $70-78$.

15. Власенко В.А., Власенко А.В., Волобуев С.В. Экологические и генетические факторы формирования морфологического разнообразия Polyporus choseniae и Polyporus ulmi // Вестник Оренбургского государственного педагогического университета. Электронный научный журнал. 2017. № 4 (24). С. 10-18.

Исследование выполнено в рамках проекта РФФИ и МКОНСМ 19-54-44002 Монг_Т. В работе использованы материаль гербария NSK (2. Новосибирск). 


\section{THE ARIDIZATION EFFECT \\ ON THE CHARACTERISTICS OF THE SUBSTRATE AND BIOTOPIC DISTRIBUTION OF FUNGI SPECIES OF THE POLYPORUS S.L. GENUS IN THE SOUTHEAST OF WESTERN SIBERIA} (C) 2020

Vlasenko Vyacheslav Aleksandrovich, candidate of biological sciences, senior researcher of Lower Plants Laboratory

Vlasenko Anastasiya Vladimirovna, candidate of biological sciences, senior researcher of Lower Plants Laboratory Central Siberian Botanical Garden of Siberian Branch of Russian Academy of Sciences

(Novosibirsk, Russian Federation)

Turmunkh Dejidmaa, PhD, senior researcher of Plant Pathology Laboratory

Plant Protection Research Institute of Mongolia (Ulaanbaatar, Mongolia)

Abstract. The paper deals with the features of substrate and biotopic distribution of fungi species of the Polyporus s.l. genus in the southeast of Western Siberia. Most species have a wide range of substrates represented by various species of woody plants. The most widespread and common species are able to develop a wide range of substrates. Rare species are distinguished by a narrow substrate spectrum. For a rare species $P$. rhizophilus, adapted to exist in the conditions of subarid regions, found only in steppe biome communities, steppe grasses (Stipa, Festuca) are the only substrate. Most species grow on deciduous wood, only some species can grow on conifers, and only the taiga species $P$. tubaeformis develops exclusively on conifers in mountainous regions. Fungi substrates are represented by 11 species of angiosperms, 3 species of gymnosperms and steppe grasses. Most species are common in numerous communities; all of them are characterized by a high frequency of occurrence and colonize a wide range of substrates. Biotopically narrowly specialized species are few in number; they are characterized by narrow substrate specialization. In anthropogenic habitats, 6 species out of 14 growing in natural communities were recorded. On the plain territory, 10 species of the genus Polyporus were identified, while 14 species were found in mountain systems, since mountain humid areas contain the largest spectrum of substrates for fungi. The greatest diversity of Polyporus species is recorded in dark coniferous forests, among which the number of species is dominated by black aspen-fir forests. With an increase in aridization and a change in plant communities, rare relict mountain taiga, nemoral and typical taiga species are eliminated. The smallest number of Polyporus species is found in the steppe communities of subarid regions.

Keywords: fungi; Polyporus; subarid regions; humid regions; polyporoid fungi; environmental structure; ecological diversity; distribution; substrate specificity; habitats; Western Siberia; plain; mountains.

$* * *$

\section{ОПРЕДЕЛЕНИЕ АНТРОПОТЕХНОГЕННОЙ НАГРУЗКИ НА ОБЪЕКТЫ ОКРУЖАЮЩЕЙ СРЕДЫ ПРИХОПЕРЬЯ}

(C) 2020

Громова Татьяна Сергеевна, аспирант кафедры ботаники и экологии

Сираева Ирина Салаватовна, аспирант кафедры ботаники и экологии

Ермоленко Анна Сергеевна, аспирант кафедры ботаники и экологии

Саратовский национальный исследовательский государственный университет имени Н.Г. Чернышевского

(2. Саратов, Российская Федерачия)

Ларионов Николай Викторович, кандидат биологических наук, директор

Котельниковская средняя общеобразовательная школа № 2

(2. Котельники, Московская область, Российская Федерация)

Ларионов Максим Викторович, доктор биологических наук, доцент, профессор кафедры биологии и экологии

Балашовский институт (филиал) Саратовского национального исследовательского государственного университета имени Н.Г. Чернышевского (г. Балашов, Саратовская область, Российская Федераџия)

Аннотация. Выявлены преимущественные источники антропотехногенных воздействий на окружающую среду городских и пригородных территорий Воронежской и Саратовской областей, входящих в субрегион Прихоперья. Среди совокупных урбано-техногенных источников следует выделить активность пешеходов и автомобильного транспорта. Эти условия характеризуют местный фон совокупной антропотехногенной нагрузки применительно к поселениям района исследований. К числу ее основных проявлений относятся уплотненность почв, плотность дорожно-тропиночной сети, захламленность. Средние арифметические значения деградационных воздействий проанализированы для поселений рассматриваемого субрегиона. Разработана шкала балльной экологической оценки состояния окружающей среды, дифференцированная по населенным пунктам Прихоперья. Высокая антропотехногенная нагрузка выявлена в г. Балашов, средняя - в г. Борисоглебск и г. Ртищево, низкая - в г. Поворино и П.г.т. Грибановский, крайне низкая нагрузка - в 